\title{
Analysis on the Return Period of "7.26" Rainstorm and Flood in 2017 in the Wudinghe Basin
}

\author{
JIN Shuang-yan GAO Wen-yong LUO Si-wu GAO Ya-jun
}

Yellow River Institute of Hydrology and Water Resources, Zhengzhou 450004, China Author: Jin Shuangyan(1974-), Ph.d, specialized in hydrology and water resources.

\begin{abstract}
The return period of "7.26" rainstorm flood in 2017 in Wudinghe basin is analyzed by the method of P-III distribution. The Lijiahe and Dingjiagou stations with long rainfall observation data in the rainstorm area are selected, and the frequency curve of the annual maximum 24 hours rainfall are established, and the recurrence period of rainfall stations in rainstorm area are estimated according to the parameters determined by the curve fitting method. The frequency curve of the annual maximum peak discharge of Baijiachuan hydrological stations and so on are established, and the return period are analyzed in combination with the historical survey floods. The results show that the return period of Zhaojiabian of heavy rainfall center is about 100 years, and which of the other stations over than $200 \mathrm{~mm}$ in Wudinghe basin is about 30 90 years; while the return period of the peak discharge of Baijiachuan and Suide hydrological station is about 30 and 20 years respectively.
\end{abstract}

\section{Introduction}

locates in the southern Maowusu desert and the northern Loess Plateau, and the basin area is $30261 \mathrm{~km}^{2}$. The Baijiachuan hydrological station is the controlling

\subsection{Research Area} station entering the Yellow River, the catchment area

Wudinghe is the primary tributary of the Yellow River, above which is $29662 \mathrm{~km}^{2}$ (shown in Figure 1).

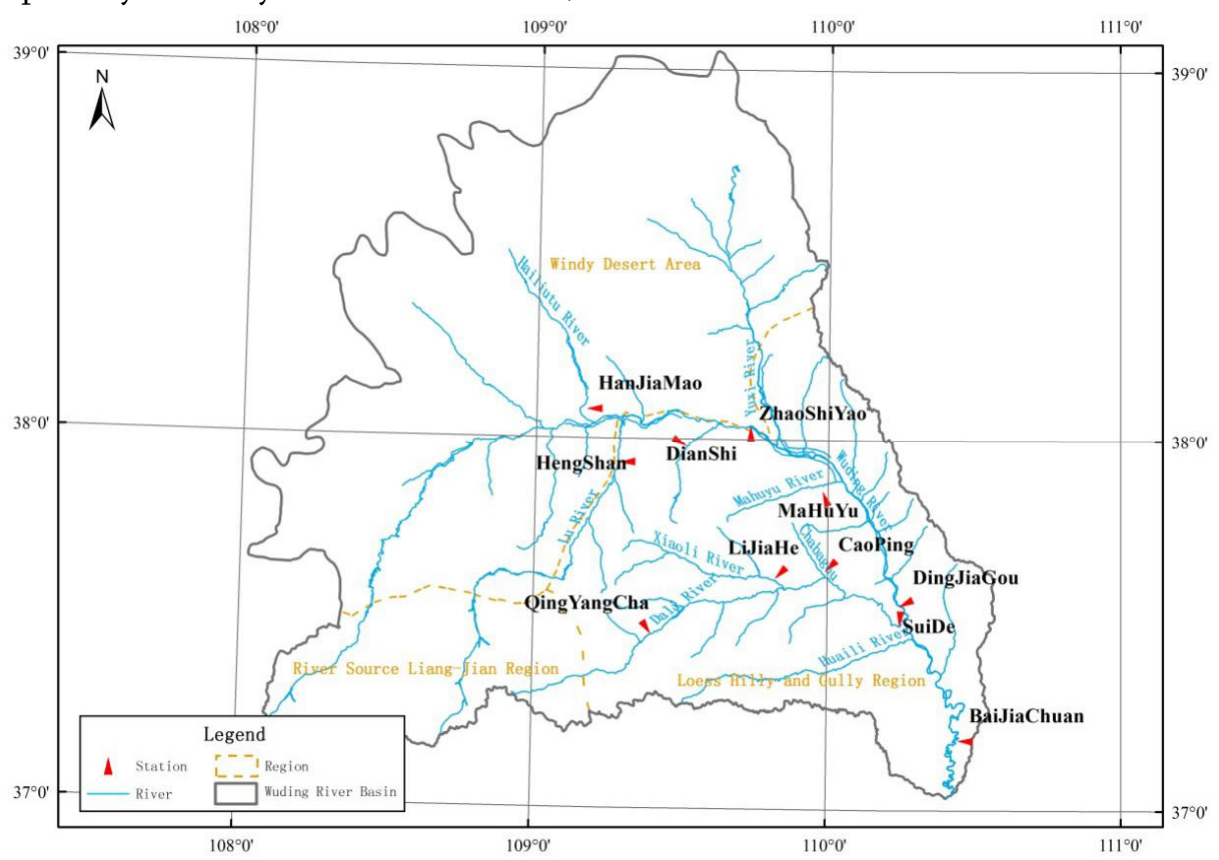

Fig.1 The location of the Wudinghe basin

According to the landform and the soil erosion characteristics, the basin can be divided into three types: 
River Source Liang-Jian Region, Windy Desert Area and Loess Hilly and Gully Region. Among them, the Windy Desert Area is located in the north and northwest of the basin, occupies $54.3 \%$ of the total area (Zhang, 2003).

Dalihe is the largest primary tributary of the Wudinghe, and the basin area is $3906 \mathrm{~km}^{2}$. The controlling station entering the Wudinghe is Suide hydrological station, the catchment area above which is $3893 \mathrm{~km}^{2}$. The whole basin of Dalihe locates in the Loess Hilly and Gully region.

\subsection{Rainstorm and Flood}

The rainstorm occurred in the most of the north ShanxiShaanxi Region of the middle Yellow River from July 25 to July 26 in 2017, and the heavy rain occurred in the tributary of Wudinghe. The rainstorm center is mainly concentrated in the Dalihe basin. The heavy rainstorm center is Zhaojiabian of Suide County, and the rainfall is $252.3 \mathrm{~mm}$. There are 34 rainfall stations with cumulative rainfall over than $100 \mathrm{~mm}$ and 10 rainfall stations over than 200mm (Tab.1 and Fig.2).

Tab.1 Rainfall over than 200mm at the stations from July 25 8:00 to July 26 8:00

\begin{tabular}{cccccccc}
\hline No. & River & Station & $\begin{array}{c}\text { Rainfall } \\
(\mathrm{mm})\end{array}$ & No. & River & Station & $\begin{array}{c}\text { Rainfall } \\
(\mathrm{mm})\end{array}$ \\
\hline 1 & Wudinghe & Zhaojiabian & 252.3 & 6 & Chabagou & Xinyaotai & 214.2 \\
2 & Wudinghe & Sishilipu & 247.3 & 7 & Wudinghe & Mizhi & 214.2 \\
3 & Dalihe & Zizhou & 218.7 & 8 & Chabagou & $\begin{array}{c}\text { Caoping } \\
\text { Zhujiayangwa }\end{array}$ & 212.2 \\
4 & Xiaolihe & Lijiawa & 218.4 & 9 & Chabagou & $\begin{array}{c}\text { n } \\
\text { Lijiajian }\end{array}$ \\
\hline & Xiaolihe & Lijiahe & 214.8 & 10 & Chabagou & Jijiajian & 200.6 \\
\hline
\end{tabular}

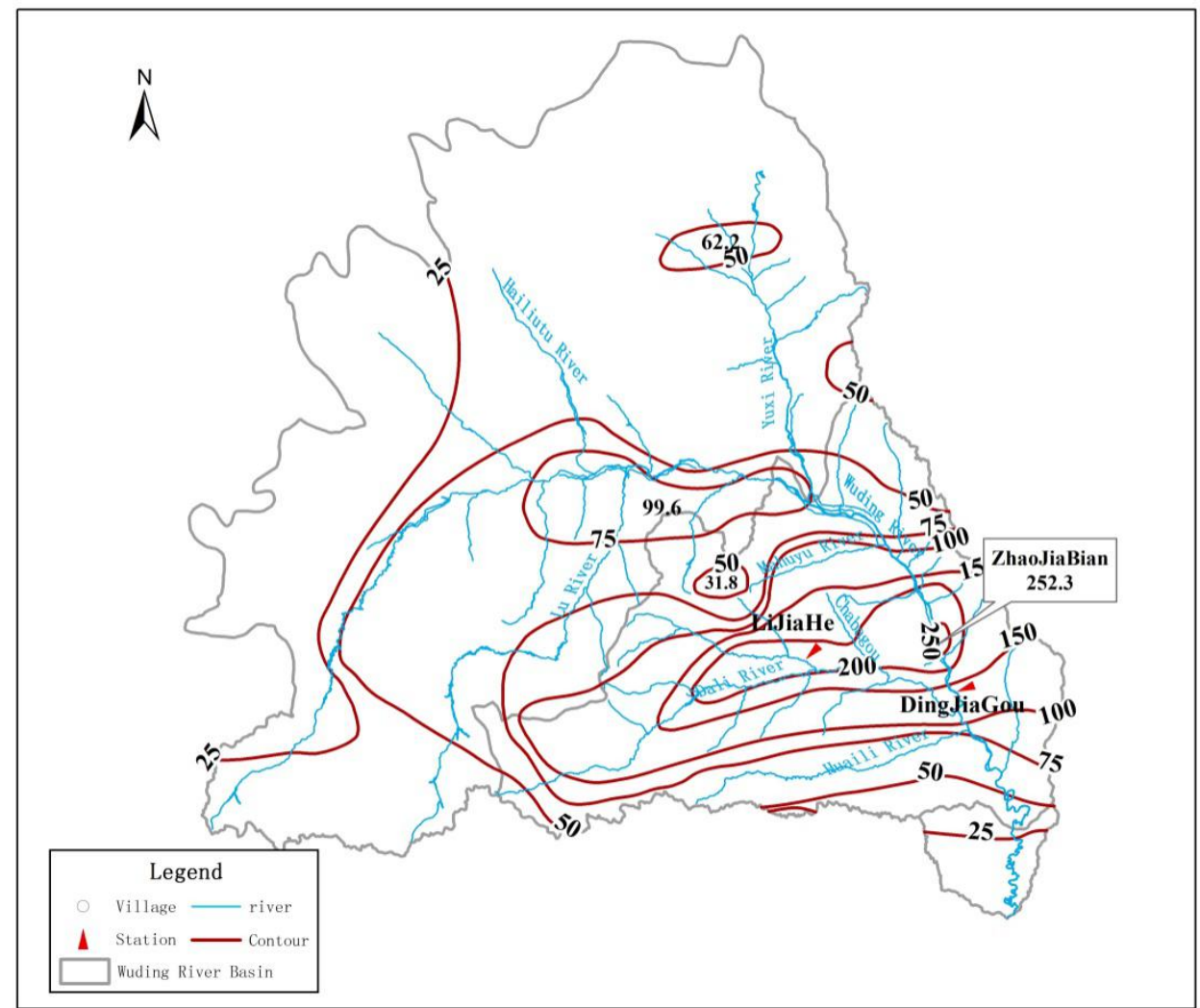

Fig.2 The isogram of rainfall in " 7.26 " rainstorm in the Wudinghe

The mean rainfall of different region from 8:00 on July 25 to $8: 00$ on July 26 in the Wudinghe basin is shown in Table 2. It is $63.6 \mathrm{~mm}$ above Baijiachuan hydrological station in Wudinghe basin. It reaches
$129.8 \mathrm{~mm}$ above Suide hydrological station in Dalihe basin, which is next to 1977 and ranks the second in history. The enveloped area of the rainfall above $100 \mathrm{~mm}$ in the Wudinghe basin is $4573 \mathrm{~km}^{2}$. 
Tab.2 The mean rainfall of different region from July 25 8:00 to July 26 8:00 in Wudinghe basin

\begin{tabular}{|c|c|c|c|c|c|c|c|c|c|c|}
\hline \multirow[b]{2}{*}{ Region } & \multicolumn{8}{|c|}{ The enveloped area of different rainfall $\left(\mathrm{km}^{2}\right)$} & \multirow[b]{2}{*}{$\begin{array}{l}\text { Area } \\
/ \mathrm{km}^{2}\end{array}$} & \multirow{2}{*}{$\begin{array}{l}\text { Mean } \\
\text { rainfall } \\
(\mathrm{mm})\end{array}$} \\
\hline & $\begin{array}{c}20 \\
- \\
25\end{array}$ & $\begin{array}{c}25 \\
- \\
50\end{array}$ & $\begin{array}{c}50 \\
- \\
75\end{array}$ & $\begin{array}{c}75 \\
- \\
100\end{array}$ & $\begin{array}{c}100 \\
- \\
150\end{array}$ & $\begin{array}{c}150 \\
- \\
200\end{array}$ & $\begin{array}{c}200 \\
- \\
250\end{array}$ & $\begin{array}{c}250 \\
- \\
252.3\end{array}$ & & \\
\hline Above Caoping & 0 & 0 & 0 & 0 & 5.6 & 158.1 & 23.3 & 0 & 187 & 177.8 \\
\hline Above Lijiahe & 0 & 35.0 & 94.9 & 289.4 & 141.6 & 113.1 & 133.1 & 0 & 807 & 121.4 \\
\hline Above Qingyangcha & 0 & 83.2 & 319.9 & 226.5 & 624.0 & 6.3 & 0 & 0 & 1260 & 97.2 \\
\hline Above Suide & 0 & 118.2 & 414.8 & 606.5 & 1549 & 715.2 & 489.2 & 0 & 3893 & 129.8 \\
\hline Above Dinggou & 3971 & 11497 & 4759 & 1847 & 562.7 & 409.1 & 334.9 & 41.2 & 23422 & 51.3 \\
\hline Above Baijiachuan & 3987 & 11988 & 6256 & 2858 & 2560 & 1148 & 824.1 & 41.2 & 29662 & 63.6 \\
\hline
\end{tabular}

The flood occurred in the trunk stream and tributary of Wudinghe in succession due to the rainfall. The peak discharge of Suide hydrological station in Dalihe is $3290 \mathrm{~m}^{3} / \mathrm{s}$, which occurred at 5:05 on July 26 , the largest flood since the establishment of the station in 1959. The peak discharge of Dingjiagou hydrological station in Wudinghe is $1660 \mathrm{~m}^{3} / \mathrm{s}$, the largest flood since 1994 . The peak discharge of Baijiachuan hydrological station is

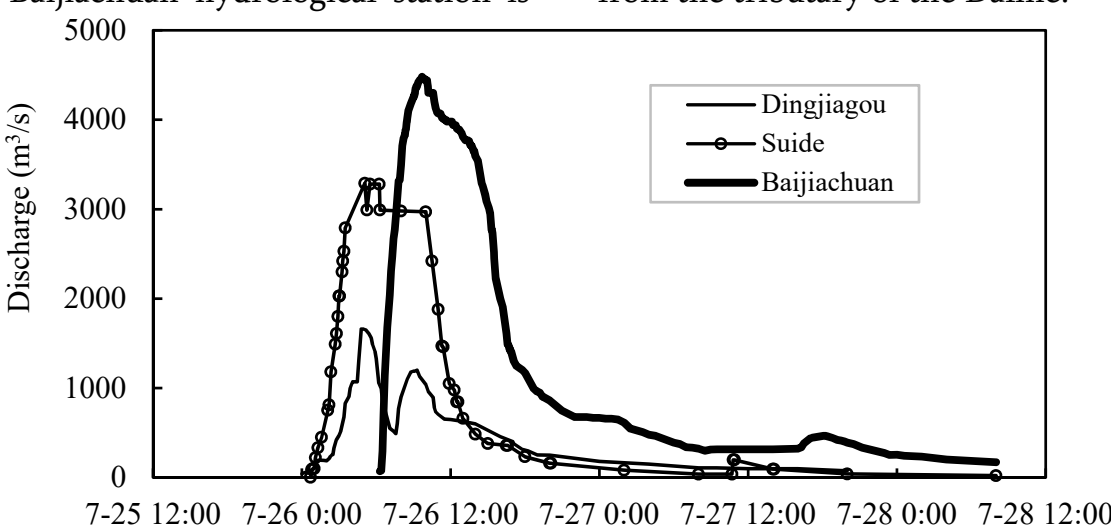

Fig.3 The composition diagram of " $7 \cdot 26$ " flood at Baijiachuan station

\subsection{The proposal of the problem}

The government and public have paid great attention to the rainstorm and flood, especially the recurrence period of heavy rain and flood.

The recurrence period refers to an average of hydrological event can occur in a number of years during long periods (Zhuang, 1995). It is a design standard widely used in the planning programming, operation and management of water conservancy and hydropower projects and civil engineering. It is mainly determined by the importance of engineering and the result of the damage to the project of hydrological events (Jin, 1964; Huang, 2011).

The rainfall of Lijiahe and Dingjiagou station with long rainfall observation data in the "7.26" rainstorm area were selected, the field survey was combined, the return period of the maximum 24 hours rainfall in rainstorm center stations, and the return period of the
$4480 \mathrm{~m}^{3} / \mathrm{s}$, occurred at $9: 42$ on July 26 , the largest flood since 1975, and ranks the second in the history.

The composition diagram of "7.26" flood in Baijiachuan hydrological station is given in Figure 3. The total water volume of " 7.26 " flood in Baijiachuan hydrological station is 166.62 million cubic meter, about $30 \%$ comes from the main stream and about $70 \%$ comes from the tributary of the Dalihe.

peak discharge in Baijiachuan hydrological station and so on were analyzed.

\section{Method}

The ultimate aim of hydrological frequency calculation is to determine the design values corresponding to the given design frequency. It is stipulates that the line type of frequency curve generally adopts P-III distribution in Regulation for Calculating Design Flood of Water Resources and Hydropower Projects (Wang, 2006).

The P-III curve is an unsymmetrical single peak and positive partial curve with infinite end at one end. The probability density function is (Zhan, 2010; Guo, 1992): $\mathrm{f}(x)=\frac{\beta^{\alpha}}{\Gamma(\alpha)}\left(x-a_{0}\right)^{\alpha-1} e^{-\beta\left(x-a_{0}\right)} d x$

Where: $\Gamma(\alpha)$, Gamma Function; $\alpha, \beta$ and $a_{0}$, the shape, scale and position parameter of the P-III type distribution, $\alpha>0, \beta>0$. 
After the integration, standardized transformation and simplification for formula (1), the equation for calculating the design value of the given design frequency can be deduced:

$x_{P}=\bar{x}\left(1+C_{V} \Phi_{P}\right)=\bar{x}\left(1+\frac{C_{V}^{2} \times C_{S} / C_{V} \times \operatorname{Gammainv}(1-p, \alpha, \beta)}{2}-\frac{2}{C_{S} / C_{V}}\right)$

Where:

$\Phi_{P}=\mathrm{C}_{S} / 2 \times T_{P}-2 / C_{S}$

$T_{P}=\operatorname{Gammainv}(1-P, \alpha, \beta)$

$\alpha=4 / C_{S}^{2}, \quad \beta=1$

Using macro command programming in Excel to find out the mean value $\bar{x}$, variation coefficient $\mathrm{Cv}$, coefficient of skew Cs and Gammainv (1-p, alpha and beta) of series $x_{i} \quad(i=1,2, \ldots, \mathrm{n})$, and draw P-III frequency curves of series $\left(p, \mathrm{X}_{\mathrm{P}}\right)$. The parameters of mean, $\mathrm{Cv}$ and $\mathrm{Cs} / \mathrm{Cv}$ are determined by the estimation of the fitting line method. According to the formula (2), the frequency corresponding to the rainfall or peak discharge is calculated.

\section{Return period of rainfall}

\subsection{Basic Data}

(1) Rainfall of the annual maximum 24 hour. The establishment year of the two hydrology stations for Lijiahe and Dingjiagou is 1959, thus the rainfall of the annual maximum 24 hour from 1960 to 2017 are selected. The rainfall of the annual maximum 24 hour is $214.8 \mathrm{~mm}$ of Lijiahe station on July 26 in 2017, ranks the first in the series. While in Dingjiagou station it is $139.2 \mathrm{~mm}$, ranks the third in the series.

(2) Transplant of Zhaojiabian rainfall

According to the transplant principle of rainstorm, the rainstorm in adjacent area should be transplanted into the series of frequency analysis, under the similar weather background, water vapor source and underlying surface conditions.

Zhaojiabian locates about $33 \mathrm{~km}$ and $12 \mathrm{~km}$ from Lijiahe and dingjiagou station. The rainfall of $252.3 \mathrm{~mm}$ in Zhao Jiabian is the heavy rain measured by Yulin Meteorological Bureau in 2017. It should be transplanted into the rainfall series of Lijiahe and Dingjiagou station to establish the frequency curve.

\subsection{Results and Discussion}

The frequency curves of the maximum 24 hours rainfall of the series from 1960 to 2017 and the transplantation value in Lijiahe and Dingjiagou station are given in Figure 4 and Figure 5. The value of $\mathrm{Cs} / \mathrm{Cv}$ is 3.5, according to the Atlas of the Statistical Parameters of China's Rainstorm (Wang, 2006).

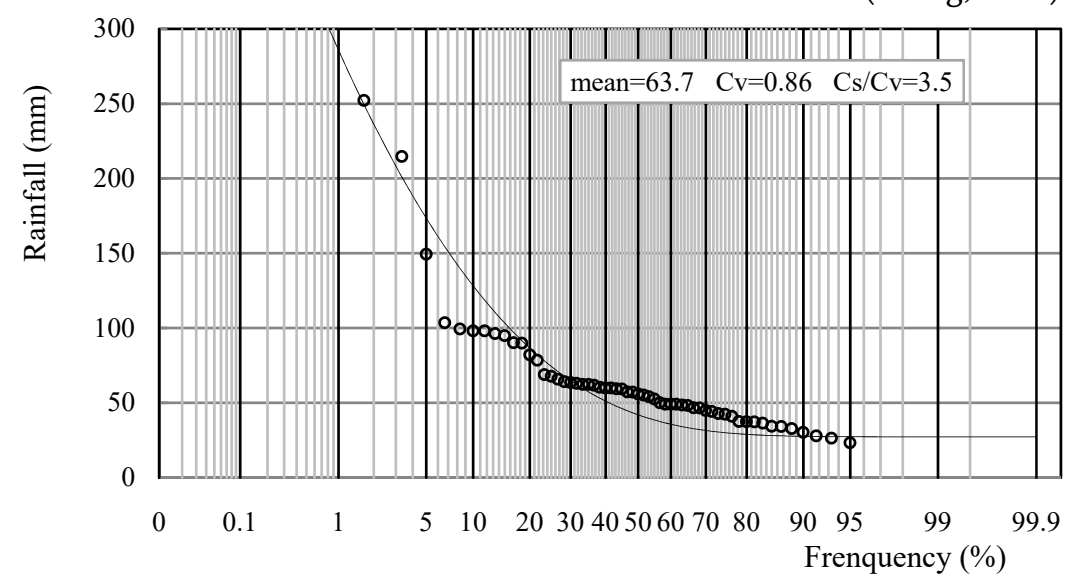

Fig.4 The rainfall frequency curve of the maximum 24h in 1960-2017 in Lijiahe station 


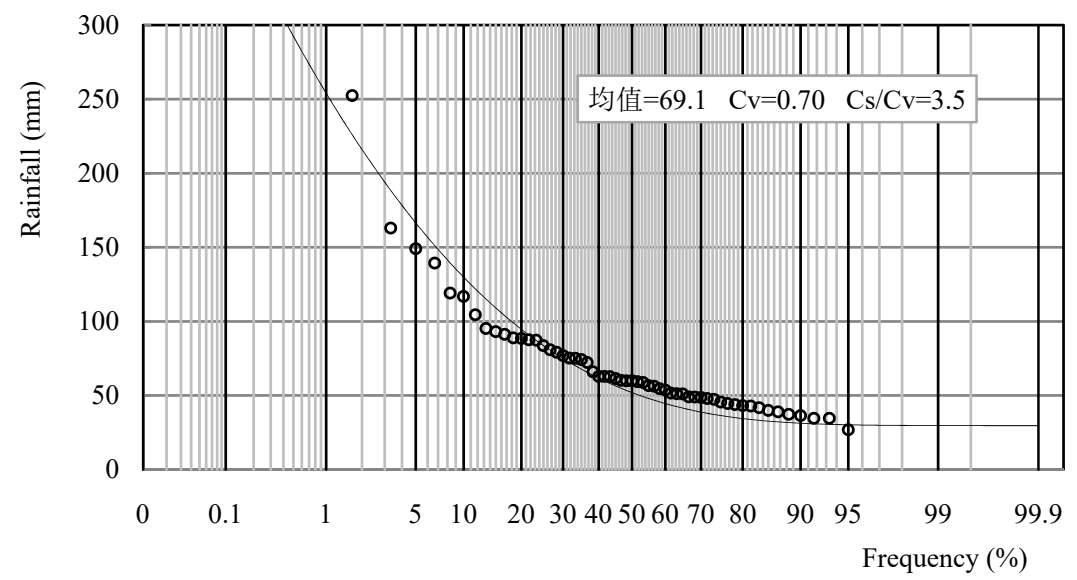

Fig.5 The rainfall frequency curve of the maximum 24h in 1960-2017 in Dingjiagou station

The recurrence period of the rainfall stations above $200 \mathrm{~mm}$ of the "7.26" rainstorm in Wudinghe basin are estimated, according to the parameters of the frequency curve of Lijiahe and Dingjiagou station. Among them, the rainfall stations in the Dalihe basin are used the frequency curve of Lijiahe station, Zhaojiabian and
Sishilipu stations near the main stream of the Wudinghe are used the frequency curve of the Dingiagou station. Therefore, the return period of the maximum 24 hours rainfall of the stations greater than $200 \mathrm{~mm}$ in Wudinghe basin is about $30^{\sim} 100$ years (Table 3 ).

Tab.3 The recurrence period of "7.26" rainstorm greater than $200 \mathrm{~mm}$ in Wudinghe basin

\begin{tabular}{cccccccc}
\hline No. & Station & $\begin{array}{c}\text { Rainfall } \\
/ \mathrm{mm}\end{array}$ & $\begin{array}{c}\text { Return } \\
\text { period }\end{array}$ & No. & Station & $\begin{array}{c}\text { Rainfall } \\
/ \mathrm{mm}\end{array}$ & $\begin{array}{c}\text { Return } \\
\text { period }\end{array}$ \\
\hline 1 & Zhaojiabian & 252.3 & 96.9 & 6 & Xinyaotai & 214.2 & 36.4 \\
2 & Sishilipu & 247.3 & 88.5 & 7 & Mizhi & 214.2 & 36.4 \\
3 & Zizhou & 218.7 & 38.8 & 8 & Caoping & 212.2 & 35.3 \\
4 & Lijiawa & 218.4 & 38.6 & 9 & Zhujiayangwan & 201.2 & 30.1 \\
5 & Lijiahe & 214.8 & 36.7 & 10 & Jijiajian & 200.6 & 29.9 \\
\hline
\end{tabular}

Similarly, through calculating and analysis, we can get that the range of return period of the maximum 24 hours rainfall of the "7.26" rainstorm in the rainfall stations of the Dalihe basin is about $3 \sim 40$ years (Table $4)$.

Tab.4 The recurrence period of all the "7.26" rainstorm station in Dalihe basin

\begin{tabular}{|c|c|c|c|c|c|c|c|}
\hline Region & Rainfall station & $\begin{array}{c}\text { Rainfall } \\
/ \mathrm{mm}\end{array}$ & $\begin{array}{c}\text { Return } \\
\text { period/a }\end{array}$ & Region & Rainfall station & $\begin{array}{c}\text { Rainfall } \\
/ \mathrm{mm}\end{array}$ & $\begin{array}{c}\text { Return } \\
\text { period/a }\end{array}$ \\
\hline \multirow{13}{*}{$\begin{array}{c}\text { Above } \\
\text { Caoping } \\
\text { station in } \\
\text { Chabagou } \\
\text { basin }\end{array}$} & Xinyaotai & 214.2 & 36.4 & \multirow{7}{*}{$\begin{array}{l}\text { Above } \\
\text { Lijiahe in } \\
\text { Xiaolihe } \\
\text { basin }\end{array}$} & Lijiawa & 218.4 & 38.6 \\
\hline & Caoping & 212.2 & 35.3 & & Lijiahe & 214.8 & 36.7 \\
\hline & Zhujiayangwan & 201.2 & 30.1 & & Lixiaohe & 179.8 & 22.0 \\
\hline & Jijiajian & 200.6 & 29.9 & & Liujiawa & 162.6 & 17.0 \\
\hline & Xiaoji & 199.6 & 29.4 & & Gaozhen & 113 & 7.8 \\
\hline & Taoyuanshan & 188 & 24.8 & & Aihaomao & 87.2 & 5.1 \\
\hline & Wangjiayan & 183.2 & 23.1 & & Dalumaotai & 68.8 & 3.6 \\
\hline & Wanjiayan & 183 & 23.0 & \multirow{4}{*}{$\begin{array}{c}\text { Above } \\
\text { Qingyangcha } \\
\text { in Dalihe }\end{array}$} & Shiyaogou & 52.2 & 2.6 \\
\hline & Niuxuegou & 181.2 & 22.5 & & Linwangetuo & 39.2 & 1.9 \\
\hline & Lijiayan & 168.8 & 18.7 & & Yangkelangwan & 79 & 4.4 \\
\hline & Dujiashan & 158.4 & 15.9 & & Qingyangcha & 161.2 & 16.6 \\
\hline & Mahuyan & 150 & 14.0 & \multirow{3}{*}{$\begin{array}{l}\text { Ungauged } \\
\text { region }\end{array}$} & Shiwan & 141.3 & 12.3 \\
\hline & Heminyan & 126.8 & 9.8 & & Zhuanmiao & 113.4 & 7.9 \\
\hline & & & & & Zizhou & 218.7 & 38.8 \\
\hline
\end{tabular}




\section{Return period of flood}

\subsection{Historical Survey Flood}

The observed flood data of Baijiachuan hydrological station is from 1956 to 2017, and the series length is 62 years. The number of historical survey flood is 1 , which occurred in August 6, 1919, and the peak discharge is $6950 \mathrm{~m}^{3} / \mathrm{s}$. The length of the data series is 99 years when considering the historical investigation flood.

The observed flood data of Dingjiagou hydrological station is from 1959 to 2017, and the series length is 59 years. The number of historical survey flood is 1, which occurred in August 9, 1932, and the peak discharge is $6180 \mathrm{~m}^{3} / \mathrm{s}$. The length of the data series is 86 years when considering the historical investigation flood.

Tab.5 The designed flood result of three hydrological stations in Wudinghe basin

unit: mean: $\mathrm{m}^{3} / \mathrm{s}$

\begin{tabular}{|c|c|c|c|c|c|c|c|c|c|c|c|c|}
\hline Station & $\begin{array}{l}\text { Catchment } \\
\left(\mathrm{km}^{2}\right)\end{array}$ & \multicolumn{3}{|c|}{ Variable/year } & \multicolumn{3}{|c|}{ Parameter } & \multicolumn{5}{|c|}{ Designed flood value $\left(\mathrm{m}^{3} / \mathrm{s}\right)$} \\
\hline Baijiachuan & 29662 & 99 & 62 & 1 & 1300 & 0.98 & 3 & 6430 & 5300 & 4500 & 3860 & 2810 \\
\hline Dingjiagou & 23422 & 86 & 59 & 1 & 820 & 1.30 & 3 & 5450 & 4300 & 3510 & 2880 & 1910 \\
\hline Suide & 3893 & 154 & 58 & 4 & 906 & 1.70 & 3 & 7000 & 5390 & 4290 & 3420 & 2130 \\
\hline
\end{tabular}

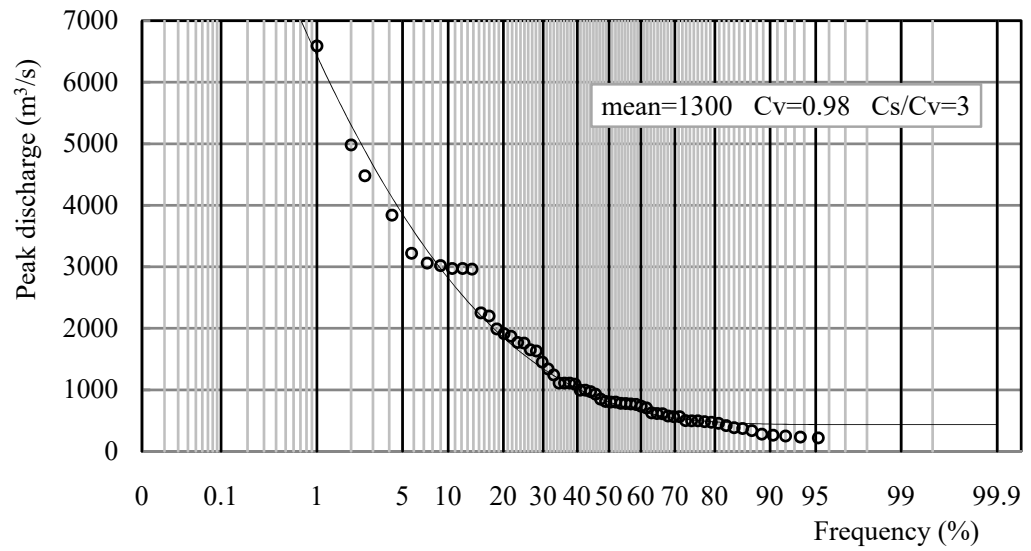

Fig.6 The frequency curve of the annual maximum peak discharge in Baijiachuan station

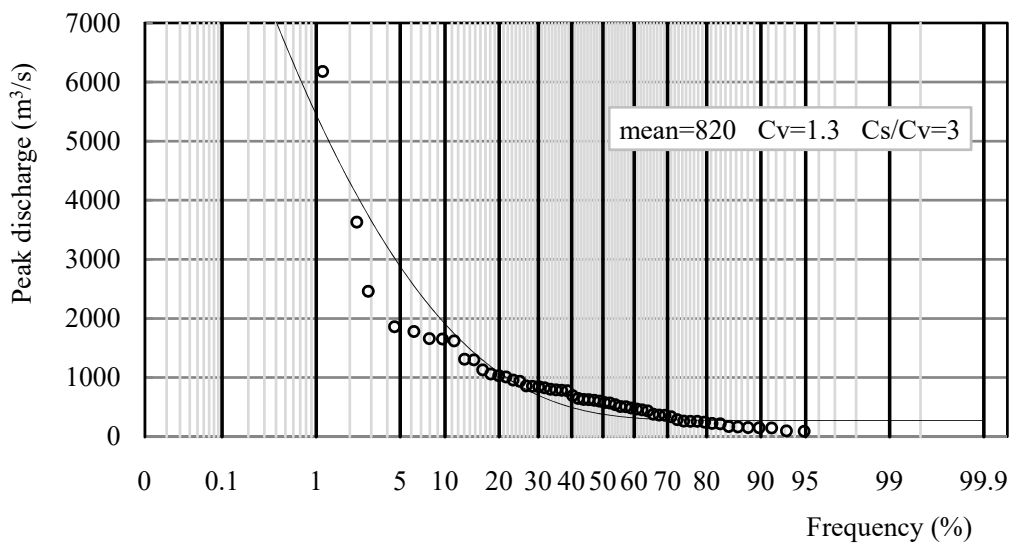

Fig.7 The frequency curve of the annual maximum peak discharge in Dingjiagou station 


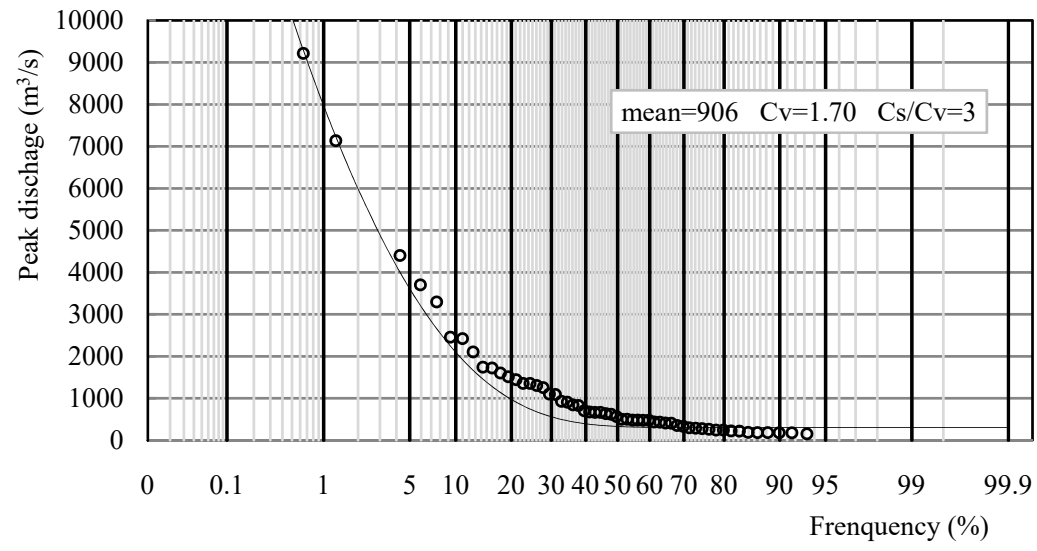

Fig.8 The frequency curve of the annual maximum peak discharge in Suide station

According to the formula (2) and the designed flood return period of peak discharge in Baijiachuan, value, the frequency and the return period Dingjiagou and Suide is about 30, 10 and 20 years corresponding to the peak discharge are calculated. The respectively, shown in Table 6.

Tab.6 The recurrence period of three hydrological stations in Wudinghe basin

\begin{tabular}{ccccc}
\hline Station & $\begin{array}{c}\text { Peak discharge } \\
\left(\mathrm{m}^{3} / \mathrm{s}\right)\end{array}$ & Series & $\begin{array}{c}\text { Frequency } \\
(\%)\end{array}$ & $\begin{array}{c}\text { Recurrence period } \\
\text { (year) }\end{array}$ \\
\hline Baijiachuan & 4480 & $1956 \sim 2017+$ historical survey flood & 3.35 & 29.9 \\
Dingjiagou & 1660 & $1959 \sim 2017+$ historical survey flood & 12.1 & 8.3 \\
Suide & 3290 & $1960 \sim 2017+$ historical survey flood & 5.35 & 18.7 \\
\hline
\end{tabular}

\section{Conclusions}

The rainfall return period of Zhaojiabian of heavy rainfall center is about 100 years, and which of the other stations over than $200 \mathrm{~mm}$ in Wudinghe basin is about $30 \sim 90$ years.

The return period of the peak discharge of $4480 \mathrm{~m}^{3} / \mathrm{s}$ in Baijiachuan hydrological station is about 30 years. The return period of the peak discharge of $3290 \mathrm{~m}^{3} / \mathrm{s}$ in Suide hydrological station is about 20 years. The return period of the peak discharge of $1660 \mathrm{~m}^{3} / \mathrm{s}$ in Dingjiagou hydrological station is about 10 years.

\section{Acknowledgment}

Foundation: National Key Technology R\&D Program (2016YFC0402401); YRIHR Program (2018ZW019).

\section{References}

1. $\mathrm{Xu}$ Jiongxin. Temporal variation of the coarse sediment yield in the Wudinghe River Basin and the cause of formation[J]. Science of Soil and Water Conservation, 2007, 5(6):1-7.

2. Zhuang Jinglin, Yu Chongcheng. Yellow River FloodPrevention Dictionary [M]. Zhengzhou: Yellow River Water Conservancy Press. 1995.

3. Jin Guangyan. The Principle and Method of Hydrology Statistics [M]. Beijing: China Industrial
Press, 1964.

4. Huang Zhenping, Chen Yuanfang. Hydrologic Statistics [M]. Beijing: China Water Power Press, 2011.

5. Wang Jun, Chen Junchi, Guo Haijin al. Regulation for Calculating Design Flood of Water Resources and Hydropower Projects [M]. Beijing: China Water Power Press. 2006.

6. Zhan Daojiang, Xu Xiangyang, Chen Yuanfang. Engineering Hydrology [M]. Beijing: China Water Power Press. 2010.

7. Guo Shenglian, Ye Shouze. The empirical frequency formula in hydrologic calculation [J]. Journal of Wuhan Institute of Water Conservancy and Electric Power, 1992, 25(2):38-45.

8. Hydrology Bureau of Water Resources Ministry, Hydrology Year Book of Yellow River Basin [M]. Beijing: Hydrology Bureau of Water Resources Ministry, 1960-2016.

9. Luo Chengzheng. Compilation of Data from the Survey of the Chinese History of the Great flood [M]. Beijing: China Bookstore Press, 2006.

10. Wang Jiaqi, Zhang Jianyun. Atlas of the Statistical Parameters of China's Rainstorm [M]. Beijing: China Water Power Press. 2006. 